\title{
Crisis in the regulation regime-a new paradigm?
}

\begin{abstract}
At the 21st SASE conference in Paris, in July 2009, a session was organized around the question of whether the financial and economic crisis would lead to the emergence of a new paradigm in the regulation regime. The following are the revised contributions of the four participants: Bruno Amable, Robert Boyer, David Levy-Faur with co-author Christine Parker, and Steven Vogel.
\end{abstract}

Keywords: regulation, markets, capitalism, crisis

JEL classification: G01 financial crises, G18 government policy and regulation, L5 regulation and industrial policy, P1 capitalist systems

\section{Bruno Amable}

University of Paris I Panthéon - Sorbonne and CEPREMAP, France

Correspondance: Bruno.amable@ens.fr

The pre-crisis doxa was based on the idea that the development of modern economies was suffering from excessive regulation and that the institutions inherited from the so-called Golden Age of the post-war years were not suited to new forms of capitalism, particularly the emergence of the 'knowledge-based society' (e.g. Sapir, 2004). The policy prescription was to implement a series of structural reforms that aimed roughly at deregulating the economy so as to increase the competitive pressure on agents. All areas of the economy were concerned: product markets were privatized and competition-regulating legislation was dismantled; the employment relationship was altered by increasing the flexibility of the labour market and reducing employment protection; and, of course, the financial system changed with the rise of market finance against intermediated finance and with capital owners given a central role over stakeholders, and financial 'innovations' generalized in a way that proposed new ways to manage risk and offered new possibilities for financial investment. The deregulation paradigm was therefore proposed as a coherent package (Braga de Macedo and Oliveira Martins, 2006). 
The recent financial and economic crisis has questioned the belief in the superiority of deregulation as a dominant paradigm for modern economies. When the world financial system was on the brink of collapse, many commentators proclaimed that this was the end of neoliberal 'self-regulated' capitalism/the AngloSaxon model. French president Sarkozy, who had been elected shortly before on a programme of neoliberal reforms, wanted to introduce subprime mortgages in France and took pride in the nickname 'Sarkozy l'américain' because of his admiration for the Anglo-Saxon model of capitalism, was led to declare the end of self-regulated markets and the victory of the European model over its American counterpart. Even The Economist (May 7, 2009), which had once held that France needed a Margaret Thatcher to turn its model into a fully fledged neoliberal economy, claimed the existence of a new pecking order in Europe: le modele français on top and the Anglo-Saxon model at the bottom.

Indeed, the financial and economic crisis is an interesting test of the 'power of ideas'. As an ideology, the doctrine of deregulation and market self-regulation was brutally devalued with the crisis; one should expect, on the basis of the force of rational arguments alone, a significant turnaround in the ideological mood and a break with the priority given to neoliberal reforms. However, if one is more sceptical about the power of ideas and more confident in the power of (economic, social, military etc.) power, one is inclined to be less convinced about the reality of the 'return of Keynesianism' or the 'return of the state'. The neoliberal reforms that were implemented more or less comprehensively in developed and developing countries over the last three decades were not so much the result of the scientific superiority of neoliberal ideas but rather the outcome of a social and political struggle between social groups. The social forces that were powerful enough to impose neoliberalization are not very likely to make amends following the near-collapse of the world financial system. To get an idea of the resistance to change, one needs simply look at what was said at a roundtable between French top managers and CEOs in January 2009: 'Do we need a better regulation [of the financial sector]? Probably. But fortunately this has nothing to do with a pseudo refoundation of capitalism' (S. Weinberg, Chairman of the Board of Accor); 'When I hear about the refoundation of capitalism, I reach for my gun' ( $\mathrm{M}$. Cicurel, CEO of the Compagnie financière E. de Rothschild, emphasis added). The general tone of the roundtable was summed up by the title given to the newspaper article reporting it (Journal des Finances, January 10, 2009): 'Top Managers Fear the Exit from the Crisis More than the Crisis Itself'. Indeed, when one's personal income is measured in millions of euros, the risk of a refoundation of capitalism is more worrying than that of unemployment.

Considering the seriousness of the financial crisis, surprisingly little has been done by way of regulating the international financial system. Most of the 
decisions taken at the various G20 meetings are based on rather mild regulatory measures (capital requirements, supervision by Central Banks etc.) and rely more on the self-regulation paradigm than on state control of financial activities. Again, considering the economic weight of the rescue plans, it would have been considered 'normal' by many (not only the general public, but also academics) to nationalize the banking system so as to avoid a particularly bad case of 'public losses, private benefits'. In the USA, the Obama administration has hesitated to take drastic measures such as the reintroduction of the GlassSteagal Act and preferred the tax instrument to initiate a separation between commercial and investment banking; and one had to wait until 2010 to see the administration adopt a moderately threatening stance against the banking industry. In Europe, much fuss has been made about bonuses and the lack of decency of bank managers in order to hide the fact that little was done to alter the fundamental features of the financial system.

The feeling of 'business as usual' that one could get is even more pronounced when attention is directed towards other institutional areas. The question of a course reversal is not even mentioned, as far as labour or product markets are concerned. The official religion of the European Union is still 'free and fair competition' that is supposed to be achieved through deregulation. The push for structural reforms is, therefore, not likely to weaken, as can be assumed from the statement of the General Secretary of the OECD: 'It is important to emphasise that the debacle in financial markets does not call into question the beneficial effects of recommended reforms of product and labour markets' (OECD, 2009).

Considering the importance of complementarities between institutions, one may gather that the reforms of the financial system are limited, out of necessity. The idea that the neoliberal agenda could be pursued in all areas but finance and that competition and deregulation would apply to all economic agents but banks and financial investors are a pure fiction. As was emphasized before the crisis, 'a liberal reform package has to be comprehensive by nature' (Braga de Macedo and Oliveira Martins, 2006, p. 4). One can hardly imagine a situation in which a simple financial patch would be applied to the whole neoliberal programme, which would remain otherwise untouched. Labour-market and product-market deregulations will lead to an increase in demand for financial services and hence the development of financial innovations. The same could be said about the privatization of education or the fiscal policy reforms favouring high incomes that have been implemented in most developed countries over the past couple of decades.

There is no ready-made 'solution' to the existing contradictions. The financial sector has its own dynamics; supported by powerful social groups, as the examples of the USA and the UK show. More fundamentally, the crisis is not simply limited to the financial sector; it affects the whole neoliberal model, in 
particular, the contradiction between the neoliberal reforms that increase pressure on wage-earners, especially those at the lower end of the income scale, and the necessity to keep up a certain pace of consumption growth for macroeconomic reasons and political stability. This contradiction was partly resolved thanks to the generalization of a growth model based on credit growth instead of real-income growth for the vast majority of households in the USA and other countries that had followed the neoliberal model. Resolving the contradiction on a long-term basis implies a reversal of the trend in income distributions in most countries, a trend that has meant an increase in inequality. Yet, how should it be possible to reverse this trend while continuing to pursue neoliberal reforms leading to de-unionization and a loss of bargaining power for wage-earners, or to the generalization of firm-based individual wage-setting in which social dumping is recognized as a 'legitimate' (i.e. 'free and fair') form of international competition, or to the intensification of fiscal competition, which prevents the establishment or threatens the stability of a generous system of redistribution?

The emergence of a new regime requires the formation of new socio-political compromises. The neoliberal regime was made possible by the formation of an alliance between financiers, firms' management and skilled workers. This alliance between finance and industry guaranteed high rates of return to capital owners and fast income growth for the wage-earners within the alliance, at the expense of the income growth for the bulk of the labour force. Breaking this alliance to find a new alliance between wage-earners and industry requires a reduction in inequality among workers: in terms of wages as well as risks (health, unemployment etc.). This reduction in inequality can be made possible only by reinforcing social protection, which is still the hierarchically superior institution. ${ }^{1}$ This also calls for renewed regulation of the labour market in order to fight the dualism between protected and unprotected workers, increase the general level of protection and re-empower labour.

The crisis should also be an opportunity to get rid of the myth of the postindustrial society, according to which emerging countries would be the world's factories and the OECD countries would specialize in service activities and hightech. Such an international division of labour is not stable; how could anyone imagine that emerging countries would be kept from $\mathrm{R} \& \mathrm{D}$ activities forever. The recent history of economic development points to an evolution in the industrial specialization of emerging countries from cheap, low-quality products to more sophisticated productions. The example of South Korea indicates the industrialization steps that today's emerging industrialized countries are probably to follow.

\footnotetext{
${ }^{1}$ On institutional hierarchy, see Amable (2003) and Amable and Palombarini (2009).
} 
Globalization and capital mobility have hindered the industrial development of many OECD countries. Thus, there is a need for active industrial policies, i.e. targeted policies based on a certain degree of protection for industrial projects in their initial phase. This differs considerably from the idea that 'passive' economic policies, ones based on creating certain economic environments, such as competition policy, should be enough. Of course, this does not fit well into the institutional frame of the European Union and its obsession with competition. There, too, a change of paradigm is required.

\section{References}

Amable, B. (2003) The Diversity of Modern Capitalism, Oxford, Oxford University Press.

Amable, B. (2009) 'Structural Reforms in Europe and the (in)coherence of Institutions', Oxford Review of Economic Policy, 25, 17-39.

Amable, B. and Palombarini, S. (2009) 'A Neorealist Approach to Institutional Change and the Diversity of Capitalism', Socio Economic Review, 7, 123-143.

Braga de Macedo, J. and Oliveira Martins, J. (2006) 'Growth, Reform Indicators and Policy Complementarities', NBER Working Paper No. 12544.

Sapir, A. (ed.) (2004) An Agenda for Growing Europe: The Sapir Report, Oxford, Oxford University Press.

OECD (2009) Structural Reforms: Going for Growth, OECD, Paris.

\section{How new will the next regulatory regime be?}

\section{Robert Boyer}

CEPREMAP, Paris, and GREDEG, Sophia-Antipolis, France

Correspondance: robert.boyer@ens.fr

\section{Twenty years of 'laisser-faire' orthodoxy challenged}

With the victory of the conservative governments of Mrs Thatcher and President Reagan and the triumph of the new classical macroeconomy, the previous regulatory regimes for goods, labour and especially financial markets have been 'reformed', i.e. largely eroded or even dismantled. A new doxa had been diffusing all over the world. The idea being that, basically, markets are selfequilibrating, State interventions are the problem and no more the solution: therefore, a light touch approach to regulation has prevailed. It was especially so for finance. 